\title{
Young Women's Narratives of Lived Experience in Face of Multiple Constraints and Barriers in Tanzania
}

\section{Ludovick Jacob Myumbo \\ 'Lecturer of Social Sciences at St. Augustine University of Tanzania. \\ Email:Ludoeve@gmail.com Tel: +255745452722}

\section{Abstract}

Young rural women in Tanzania lack opportunities to speak about themselves and their lived experiences. This study employed participatory narrative inquiry (PNI) to afford a space for young rural women who relocate to urban centres for a better life to tell stories of their lived experiences. In relocating to urban centres, young rural women hoped to find decent work to earn an income but the lack of qualifications required for employment in the formal sector in the urban centres expose them to unconventional and dehumanizing livelihood strategies, including sex work. The study gives an insight that patriarchy in rural areas of Tanzania creates gender inequality to the extent that young women lack opportunities for self-actualization and for a better life. Hence there is a need to comprehend and disrupt unfair structures that limit and prevent opportunities and independence for young rural women in Tanzania.

Keywords: Young rural women, Narratives, Livelihoods, Lived experiences, Constraints, Servitudes. JEL Classification: I39 Welfare, Well-Being, and Poverty: Other

Citation | Ludovick Jacob Myumbo (2021). Young Women's Narratives of Lived Experience in Face of Multiple Constraints and Barriers in Tanzania. Asian Journal of Social Sciences and Management Studies, 8(1): 7-14

History:

Received: 4 January 2021

Revised: 29 January 2021

Accepted: 15 February 2021

Published: 1 March 2021

Licensed: This work is licensed under a Creative Commons

Attribution 3.0 License (cc))

Publisher: Asian Online Journal Publishing Group
Funding: This study received no specific financial support

Competing Interests: The author declares that there are no conflicts of interests regarding the publication of this paper.

Transparency: The author confirms that the manuscript is an honest, accurate, and transparent account of the study was reported; that no vital features of the study have been omitted; and that any discrepancies from the study as planned have been explained.

Ethical: This study follows all ethical practices during writing.

\section{Contents}

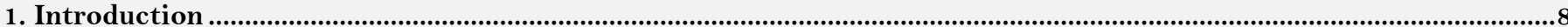

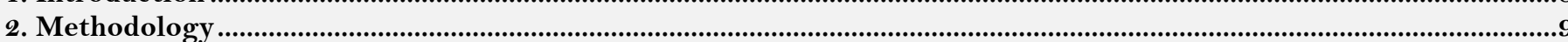

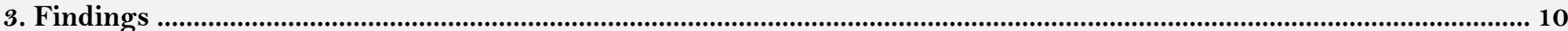

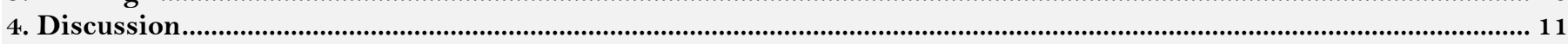

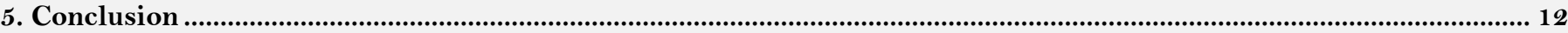

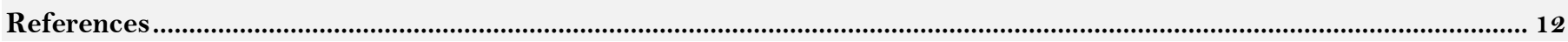




\section{Contribution of this paper to the literature}

Women's welfare and well-being. It argues for the need to work effectively in ways that can disrupt gender inequality in Tanzania. Second, the approach of this study is relatively new in the world of qualitative research - a new way of thinking about and studying lived experience. In that respect, the study contributes to methodological approaches in qualitative research, particularly for the effective study of sensitive topics.

\section{Introduction}

During my years of working with local communities in Mwanza town, as part of the outreach programmes of St. Augustine University of Tanzania, I met a young rural woman who had been lured into sex work by men who always look for young women migrants to exploit and abuse, as soon they arrive in the city. I was moved in tears when I heard her many stories of abuse and exploitation. I passionately wanted to do something about this state of affairs. As a person who had been socialized into patriarchy, I felt that I bore more responsibility for disrupting men's oppression of women, which is perpetuated through male privilege, male roles and exaggerated masculinity (Hearn, 2012).

What happens in Tanzania is that young women, from rural areas, often relocate to urban centres for better opportunities for their livelihoods. This is due to the situation in rural areas which is characterized by destruction, disease and decline - social environments in which the possibilities of living decent lives and fulfilling one's goals are bleak (Christiansen, Utas, \& Vigh, 2006; Stark, 2017). This is especially critical for young rural women who lack opportunities for self- actualization and well-being (Hagues \& Parker, 2014). In relocating to urban centres, young rural women hope for salaried jobs, stable incomes, viable lives and predictable futures (Msigwa \& Mbongo, 2013).

What is most tricking in the process of young rural women relocating to urban centres for better livelihoods, however, is the general lack of reliable information and public awareness as the circulation of information regarding lifestyles and the availability of 'employments' in the cities occurs informally through personal networks within the home territories (Kibuga, 2000; Swantz, 2007). The operations of local recruitment agents, for example, go uninspected or unmonitored by state authorities (Msigwa \& Mbongo, 2013). This is critical, given that a young woman from a far-flung rural place might be as much a stranger in an urban centre as a migrant worker from abroad. She might come from an ethnic group that is different from those of her employers; speak a different dialect or language; practise a different religion; be illiterate (in the sense of being unable to read, write or count); or simply be overwhelmed by the customs and beliefs of urban households and/or workplaces - feeling isolated in a strange and volatile environment while trying to strategize for her livelihood (ILO, 2013).

Furthermore, a young woman from a rural area with little or no formal education may experience restricted access, or be denied access altogether, to information and services relevant to her personal and/or work life. Her situation may become even worse if the terms and conditions of her 'employment' are fluid, undefined and unwritten, all of which happens in informal sectors in Tanzania and across sub- Saharan Africa (ILO, 2013).

In such complex, fluid and undefined circumstances, a young rural woman may lack the means to speak out about instances of mistreatment and exploitation, and may have no way to seek redress for abuse and maltreatment. Because of such constraints and barriers, including a lack of qualifications, young rural women may find themselves in informal 'employments' which offer low wages and expose them to exploitative and inhuman environments. In other words, they may feel compelled to engage in unconventional livelihood strategies, such as sex work for their survival.

This is especially critical in contexts of human misery and high rates of economic and social deprivation in Tanzania, where young rural women may simply be led or deceived into accepting the promises offered by human traffickers or town-based brokers without being aware of the precarious types of 'employments' or conditions that await them in urban centres (Kiaga, 2007; Msigwa \& Mbongo, 2013).

\subsection{Problem}

There are no substantive qualitative studies in Tanzania which explore and understand the lived experiences 1 of young rural women who relocate to urban centres for better livelihoods. It is therefore perhaps fair to say that the information about the phenomenon of young rural women who relocate to urban centres for better livelihoods often comes from the perspectives and voices of 'outsiders', whether those be elite urban residents, policymakers or other privileged commentators. As a result, the voices of these young rural women recounting their situations from their own perspectives are rarely heard. This does not mean that the existing information and perspectives are unfair or untrue. They might be entirely true.

However, to insist only on other people's perspectives and narratives about these young women risks voicing only part of the story, with the result that our understanding of their lived experiences might be curtailed. Adichie (2000) contends us that partial or isolated stories often lead to stereotypes, and the problem with stereotypes is not that they are untrue, but that they are blind and incomplete. Stereotypes make one story become the only story, and therefore limit any deep exploration of the "multiple interpretive possibilities" and "discourses existing beneath or alongside the primary narrative" (King, 1998).

This shortcoming leads to stereotypes which perpetuate skewed perceptions and connotations, categorizing such young women as deviant and vicious (Matthews, 2008) thus reducing them to numbers for the purposes of creating an 'other' to be controlled (Quinn \& Rosenthal, 2012).

${ }^{1}$ Lived experience designates first-hand accounts and/or impressions of living as a member of a group or society (Boylorn, 2008; van Manen, 1990). It refers to individuals' unique outlooks and perspectives, which are shaped by subjective factors of identity such as race, class, gender, sexuality, religion, political associations, roles and other characteristics that determine how people live their daily lives in a group and/or society (Boylorn, 2008). In other words, lived experience signifies individuals' unique accounts in a society in comparison with others (Boylorn, 2008). These unique accounts can be life-affirming or negating, depending on one's experiences of ordinary and everyday events (Boylorn, 2008). 


\subsection{Objective}

The main goal of study was to provide a platform for young rural women who relocate to urban centres for better livelihoods to recount their situations from their own voices and perspectives. It sought to answer this question: what are the lived experiences of young rural women who relocate to urban centre for better livelihoods in Tanzania? Although this question does not address all the urban areas in Tanzania, but only in Mwanza, it largely covers two important issues facing young rural women who relocate to urban centre for better livelihoods in Tanzania: their everyday lived experiences (both past and present), and their experiences in their workplaces, including how they negotiate to find employment, the types of employment available to them, and the other viable options for their livelihoods. All these issues were raised to inform us not only about how young rural women strategize for their livelihoods in the face of multiple constraints and barriers, but also how they comprehend agency in their respective environments, as well as how they envisage and shape their own futures. This was important in the context where women's voices have been restricted and the opportunities for them to speak about themselves and their lived experiences have been almost non-existent (UNICEF, 2006).

This study, therefore, intended to afford a space for the marginalized and silenced to speak about themselves and allowed them voices, perspectives, and agency in articulating their stories, so as to counteract the abundant dominant prejudices about these young women. On the defence of this, Atkinson, Coffey, and Delamont (2003) write that allowing or "giving voice to the subjects includes the representation of individuals and groups who have been muted and marginalized. It implies the expression of their unique experience, usually through the reproduction of personal testimony and narrative." In the same line of thought, Blatt (1981) argues that a person is defined by the stories she tells about herself as well as by the stories that are told about her. Then Bogdan and Biklen (1998) describe facilitating voices as "empowering people to be heard who might otherwise remain silent" or who have been silenced by others.

\section{Methodology}

To achieve the above objectives, Kurtz (2014) participatory narrative inquiry (PNI) was found pertinent approach. PNI is an inductive approach which blends participatory and narrative approaches for a group of people to work through stories of personal experiences so as to unravel their complex situations (Kurtz, 2014). PNI takes into account social contexts, beliefs, feelings and perspectives in obtaining new knowledge (Kurtz, 2014). It emphasizes 'meaning' as something that exists in its own right, and not as something we just find out there; meaning is given as human beings interact and interpret their conditions in a particular social context (O'Leary, 2004).

I largely became captivated by PNI because it provides a narrative mode through which the participants make a sensible reading of the 'world' based on authentic experiences (Abbott, 2008). This is because narrative can be, and often is, an instrument that provokes affective thinking about events through talking about them and hearing them being told (Abbott, 2008). It is said that "memory itself is dependent on the capacity for narratives," for "we do not have any mental records of who we are until narrative is present as a kind of armature, giving shape to the records that are in our minds" (Abbott, 2008). Without the told narratives, opinions might be formed, but the magic and value embedded in storytelling for shaping memories disappears (Kurtz, 2014).

What an inquirer or researcher in the PNI process does is to collect stories, asks questions, and lets the participants look at, think and talk about the patterns themselves, but does not decide for the participants what the stories might mean (Blumer, 1954; Kurtz, 2014). In doing so, PNI deeply immerses the inquirer or researcher in the world of the participants and leads the inquirer or researcher to 'de-experience' and 'de-world'2 the world of participants with the hope of gaining in-depth understandings of their lived experiences (Guignon, 1999; Safranski, 1998).

\subsection{Data Collection}

Informed by the literature that young rural women who relocate to urban areas for their livelihoods are often employed as house or bar maids (Kibuga, 2000; Msigwa \& Mbongo, 2013) and knowing that a thin line exists between barmaid and sex worker in Tanzania, I decided to visit bars in the neighbourhood and make contact with potential participants in the study. This task would fall into what Dickson and Green (2001) call "bridge activity something short term to help with entering a site or community, and giving its members a chance 'to size you up and get to know you." I soon became acquainted with two young rural women who worked in a popular bar on the main road to Musoma, and a purposeful dialogue and reflexivity started from there onward (see also (Shaw, 2010; Watt, 2007)).

I can recall how difficult the initial contacts the two young women were as I attempted to explain the study and relate it as humanly as possible. It was not easy at all as it required a considerable inner change of attitude and behaviour on my part, particularly in my attitude towards the young women who were surviving in and negotiating a complex body-related industry for their livelihoods. I needed to learn and practise, for example, how to ask delicate questions in a non-offensive manner. I became conscious of the need to be friendly, courteous, conversational and unbiased. In this regard, I had to strike a balance between being humorous and serious. I also learnt to be patient and in a respectful manner. The idea was to put the young rural women at ease so that they could be themselves and talk freely.

I decided, therefore, to use a snowball sampling technique (Maher, 2000) to reach out to other young rural women in their respective situations as some of the places where some of them worked and/or lived were staffed by men and women who would certainly not be pleased with my idea of researching 'their girls', especially during working hours. In this regard, my initial relationship with the two young women became providentially helpful. This was possible thanks to the solidarity that exists amongst the young rural women who work as barmaids but also trade sex in Mwanza town. The truth was that these young rural women knew each other well and met 2 The terms 'de-experience' and 'de-world' are used here in Heidegger (2001) sense, which presumes that if we reduce our understanding to an objective
opinion, bracketing out all prior experiences and emotions, then we may ultimately bracket out the meaningfulness of the experience we are trying to explore; we de-experience the experiences and de-world the world as we encounter others in their present situations (Guignon, 1999; Safranski, 1998). 
regularly for social and psychological support. I therefore had a rare and important opportunity to 'enter' their wider community, in which I became 'a member of the landscape' (Clandinin \& Connelly, 2000).

As soon as rapport had been built between the young rural women and me, I purposefully recruited six participants for my research, for several reasons. First, a relatively small number of participants would foster trust more easily. Second, a small number of participants would keep the process personal and active, and would make our contact more direct and consistent (Ospina, 2004). Third, with a small number of participants, we could access thick and rich data, which is an important aspect of qualitative research (Langdridge, 2007). I targeted young rural women aged between 18 and 25 years, an age group that I thought would articulate their lived experiences well. The PNI process placed us in a friendly and supportive context; we felt protected and confident as a group, and became less anxious. Apart from sharing stories of lived experiences, we also spent time together eating, drinking and sometimes dancing. I sometimes stayed with them until midnight. However, this required patience on my part, and understanding from my family and society at large.

Keeping a field diary was important in this process of narrative inquiry. In it, I documented almost everything that I heard, observed and found. My field diary contains the evidence on which my research is based. I always took notes in our meetings so that I could focus on the person, using journal records (pondering) (Savin-Baden \& van Niekerk, 2007). I also conducted unstructured open-ended interviews that were dyadic or one-to-one (see also (Hofmann, Puzicha, \& Jordan, 1998)). Written or visual documents such as personal text messages, photos of the participants or artworks, for example, were also collected as important pieces of information. This process of narrative inquiry revealed that statements became more meaningful within the context of a story (see also (Clandinin \& Connelly, 2000; Riessman, 2008)). Therefore, taking notes on where and when the narrative emerged, and the circumstances surrounding it, was very important (Ellett, 2011). I chose not to tape-record the participants as some of them were nervous about tape recorders and did not want to be recorded, especially on this sensitive topic ${ }^{3}$, which is concerned with their intimate lived experiences. Therefore, I felt it was not mandatory to make any audio recordings of the PNI process.

In the process of analysing the stories, I organized my data into three main areas: past experiences, current experiences and future aspirations. In doing so, I was guided by Strauss and Corbin (1998) recommendation to allow new themes, knowledge or theory to emerge from the data, without any restraints imposed by structured methodologies (see also Thomas (2006)). I liked this method of data analysis because it involves relating the facts obtained from the field (empirical data) to concepts drawn from models or theories - that is, it is data-driven analysis (Braun \& Clarke, 2006). In addition, this way of data analysis as part of the general inductive method would immerse me in the raw material so as to allow me to look for more details and establish patterns of relationships (Braun \& Clarke, 2006).

My inquiry included a process of reflexivity, not only to account for any power imbalances, but also out of consideration for the validity and reliability of the data (Maxey, 1999). With reflexivity, I was made aware of stereotypes, and I was often reminded to act only as a catalyst to promote inquiry into issues that affected the participants (May, 2000). I should also say here that although it has been claimed that most researchers have organizational and institutional power (Henry, 2003) this was not strongly the case in this study (see also Grenz (2005)). Quite often, I experienced varying levels of power in different phases of my research. At some stages, I felt that power was fluid and possessed by nobody - neither the participants nor I - an idea also noted by Tang (2002). At the beginning of the study, for example, I felt powerless while trying to recruit the participants, afraid that they would lose interest in the PNI process. I struggled several times to enhance the sense of rapport between the participants and me, or among the participants themselves, so as to build a considerate and sympathetic relationship - a sense of mutual trust (see also Karnieli-Miller, Strier, and Pessach (2009)).

\section{Findings}

The participants were urged to narrate why they had left home, left everything, to go to Mwanza town. In what ways might their choices possibly have been coerced? From the stories narrated, an array of situations which had led them to prefer urban lifestyles were revealed, ranging from broken homes due to the loss of parents or guardians, to gender discrimination and economic independence. Some participants particularly described being brought up by harsh stepmothers or cruel and unfair relatives, and in abusive environments, making it almost impossible to lead a sane life. They also described a lack of people to trust and confide in as one of the reasons for moving out of their localities. In some cases, the very people they relied on for survival turned out to be their abusers.

Notably, the participants repeatedly narrated how gender inequality and oppression were interwoven into the social fabric of their rural family and society. They particularly pointed out that their rural family was organized in such a way that girls were socialized to accept lower status and to view themselves as less human and less valuable not only in the family itself but also in the community at large. They underscored how social and cultural notions about 'real men' loaded all the heavy domestic tasks and chores onto girls' and women's shoulders. These tasks, unfortunately, were hardly valued and limited girls' potential for education and other productive prospects as girls were generally considered economic and social liabilities (lacking income-earning capabilities) that only drained the household wealth with no hope of return.

In the hope of escaping onerous gender restrictions and parental control, some participants dreamt of the 'freedom' they would obtain by living away from home. They particularly narrated their deeply held wishes to be independent and free from patriarchal constraints. They often used phrases that illustrated how free they felt in comparison with the pasts. Phrases such as 'nobody checks anyone,' 'you do whatever you like' and 'you oversee your own life' were commonplace. Unlike their controlled peers in the rural areas, the participants cherished the ability to do whatever they liked, despite the consequences of that freedom. They were delighted to be out of the reach of the customs and social arrangements which had restricted and constrained their voices and choices.

\footnotetext{
${ }^{3}$ Research is described as sensitive if it requires a disclosure of behaviours or attitudes which would normally be kept private and personal, or if it tackles issues which might result in discomfort or offence for those taking part in the research (Dickson-Swift, James, Kippen, \& Liamputtong, 2006).
} 
Speaking about their current experiences of working as barmaids but also trading sex for their livelihoods in Mwanza town, the participants narrated different forms of violence which had much in common with other kinds of gendered violence such as sexual harassment, stalking, rape, battering, torture and other injustices. They recounted experiencing a dilemma in the sense that they tried to be normal, to feel that they were doing 'fairly okay' for their own and their family's survival, yet they felt deeply stigmatized. When they were asked which specific aspects were linked to social stigma, they initially answered that bar maiden and sex work were highly unwelcome in Tanzania. Because those activities were unwelcome and also criminalized for the case of sex work, some people come to believe that stigmatizing or even abusing a barmaid or sex worker is justifiable, as she is seen as a 'criminal' who deserves no good. As a result, the young women felt ashamed for being deviants from the social norm and were often forced to live hidden lives or to lie about themselves, often leading to burnout and depression. Their stories contained vivid examples of how they were often abused as they were often depicted as deviant, vicious, depraved and fallen - forever damaged by immorality, and beyond redemption.

On their future aspirations, against the above view, a fair number of the participants thought that their present life in Mwanza town was better than their previous life in the rural areas. They cited economic independence, access to social networks, increased mobility, and the ability to support their families back home as signs of better livelihoods. However, the feelings of unfinished business, of not having gathered enough resources to adequately support the family back home, held them hostage in the servitudes in urban centres. Therefore, they wished to change their lifestyle only if other options became available, mentioning possibilities such as setting up small businesses or investing in farming. Some of the participants had already taken concrete steps to become entrepreneurs, but still wanted to achieve more, to earn cash before moving into an alternative lifestyle and/or returning home.

\section{Discussion}

It was clear that most of the young women fled their homes because girl and young women in rural areas experience increased hardship due to oppressive and violent structures embedded in social relations within patriarchy, as also reported in other studies in Tanzania (Buberwa, 2016; Ellis, Blackden, Cutura, MacCulloch, \& Seebens, 2007; Hagues \& Parker, 2014; Msigwa \& Mbongo, 2013; Silberschmidt, 2001; Wamoyi, Fenwick, Urassa, Zaba, \& Stones, 2011) in Botswana (Mookodi, 2004) and Zimbabwe (Kambarami, 2006). Most of these studies maintain that from a tender age, girls are taught to be gentle, obedient, passive and submissive housekeepers, a process which leads to gender inequality in the family and in society at large. The division of labour in the household, for example, demands that girls and women must work much longer hours than men (see also (Bayles \& Bujra, 2000; Setel, 1999; Varkevisser, 1973)). Whilst this family work gives women some power in specific spheres, in general it greatly benefits men who are owners of land and or/household (Akeroyd, 1997) a fact which some men recognize (Swidler \& Watkins, 2007). As a result, rural women are far less able to sell their labour in comparison with men, and remain of lower social status, culturally inhibited from asserting their interests in public (Akeroyd, 1997; Bayles \& Bujra, 2000). In these contexts, girls and young women in rural areas may feel compelled to relocate to urban centres in hopes of being free from patriarchal constraints - to claim forms of autonomy and freedom and to create a different future (McDowell \& Pringle, 1992).

While trying to strategize for their livelihoods as barmaids and sex worker in Mwanza town, young rural women were often abused because they were often depicted as deviant, vicious, depraved and fallen young women forever damaged by immorality beyond redemption. This is also supported in the literature that bar maiden and sex work do not generally tally with traditional and social norms in Tanzania (Beckham, 2013; Wamoyi et al., 2011). Women are generally expected to maintain their sexual respectability, and this norm is particularly important in relation to negotiating sex work and other servitudes (Wamoyi et al., 2011). Haram (2005) writes that sex workers are particularly denounced in Tanzania primarily because they go against the "cultural logic of secrecy in sexual life." Implying that it is not the exchange of sex for money that violates social norms in Tanzania; rather, it is the public acknowledgement or flaunting which is connected to extramarital relationships that is condemned and brings 'shame' to women (not to men). In other words, it is the explicit solicitation of sex (to have sex with many partners as barmaids or sex workers are thought to be) with relatively little selectivity or discretion that is condemned and brings 'shame' to women. As long as women maintain secrecy about their sexual relationships, they also maintain respectability (Beckham, 2013).

Indeed, bar maiden is unwelcomed and sex work is criminalized in Tanzania (Beckham, 2013) which justifies why some people believe that abusing or stigmatizing a bar maid or sex worker is right, as she is seen as a criminal who deserves no good (Beckham, 2013) as also reported in other countries in sub-Saharan Africa (Ngugi, Roth, Mastin, Nderitu, \& Yasmin, 2012; Scheibe, Drame, \& Shannon, 2012; Scorgie et al., 2013). This explains why some feminists, particularly liberal and radical feminists, argue against the criminalization of sex work (Bindel, 2017). In their views, if sex work is legalized, some criminal aspects of it can be controlled, which could also reduce social stigma and sexual exploitation (Bell, 1987; Daly, 1985; MacKinnon, 1993; Rubin, 1984).

While it is true that some poor women are compelled to have sex with wealthier men to meet their own basic needs (personal and family needs), it is also true that in sex work there is a continuum between 'survival sex' and sexual transactions in which women strive to obtain desirable consumer goods in order to enhance their social status (Leclerc-Madlala, 2003; Stark, 2017) making quite hard to quit or to seek alternative life options. What is implied here is that in the structure of gender inequality where men hold the money and the power, sex is just one commodity among others used by poor women to bargain with wealthier or more powerful persons (LeclercMadlala, 2003; Preston-Whyte, Varga, Oosthuizen, Roberts, \& Blose, 2000; Stark, 2017). In other words, sex work offers "a space in which impoverished young rural women in urban centres renegotiate their identities and actively imagine for themselves a better future" (Stark, 2017). No matter how ugly and dehumanizing sex work is, it is a commercial enterprise within capitalist patriarchy, and evidence strongly suggests that women who engage in it do so primarily, and often exclusively, for economic reasons, albeit in contexts of limited choice (Overall, 1992). Bass (2015) writes that "just as sex work can be an avenue for some women to take control in a situation where they had none, some sex workers and psychologists see it as a way to triumph over tragedy." This means that in a context of 
men's economic power and women's economic insecurity, women may feel compelled to 'choose' sex work for survival and financial gain (see also (Farley, 2006; Kempadoo, 1999; Overall, 1992)).

The above is especially true in context where sex workers and barmaids often assume the responsibilities of mothers (Basu \& Dutta, 2011; Delacoste \& Alexander, 1987; Zalwango et al., 2010) which gives them respectability for their families (Haram, 2003; Hollos \& Larsen, 2008). Haram (2003) has particularly observed in tanzanite that some women who are considered sex workers by outsiders (other members of society) see themselves as single mothers who strategically enter and exit partnerships with men for material gain for their families. In that context, sex work is just one job among others used by poor women ('mothers') to gain income and be able to support their 'children' or other members of the extended family (Mbonye et al., 2012; Scorgie et al., 2012; Zalwango et al., 2010). This means that, although sex work can be extremely difficult, when it is driven by both 'poverty' (survival) and 'want' (desire for consumer goods), some women may find it hard to exit it or may simply decide not to leave it unless they have other means to alleviate their lack of income for their well-being and social status.

\section{Conclusion}

It is shown in this stud that patriarchal structures in rural areas in Tanzania deny young women opportunities for self-actualization compelling them to relocate to urban centres in the hope of finding salaried jobs, stable incomes, viable lives and predictable futures but their lack of qualifications, skills and abilities required for employment in the formal sector in the urban centres, they find themselves relegated to the informal sector, which expose them to unconventional and dehumanizing livelihood strategies, including sex work. Even though sex work offers social and economic independence for poor young rural women, and even though some scholars contend that trading sex is just one form of unpleasant labour among many others in the neoliberal economy, similar to factory work (Hardman, 1997; Smith \& Marshall, 2007), sex work is a nightmare and it hurts. It is a nightmare because it is a way of life that is stigmatized by much of society, that is physically dangerous at times, that leaves young women with little control over their bodies or earnings, and that causes them considerable legal and health complications (Bartlett, Rhode, Grossman, \& Buchalter, 2014; Bindel, 2017). In that context, sex work is a form of exploitation of women who are exclusively victims within the patriarchal system of exchange. Whether it is done by choice or not, sex work is a practice which is constructed within a system that reinforces male supremacy where women service men's sexual needs and desires (Farley, 2006; Farley et al., 2003; Overall, 1992). In other words, sex work is an extension of male privilege within patriarchy (Overall, 1992; Rubin, 1984) but because it is driven by poverty, young rural women cannot simply decide to leave it unless they have other means (better options) to alleviate their lack of income.

It is recommended, therefore that while the young women in this study can be considered adults - independent, autonomous, and able to make decisions, to defend and protect themselves and those in their care - it is important to be aware of the oppressive and abusive relationships which plague many young rural women in patriarchal society. There is a need to explore and comprehend the factors or even structures that limit and prevent opportunities and independence for young women in rural areas in Tanzania. If unfair structures are not disrupted and broken, there remains the danger of perpetuating stereotypes and the culture of blaming ill-treated and weak individuals. As a social worker myself, I argue social work professional in Tanzania to be actively present and engaged with affected (ill-treated and weak) individuals, letting their voices be heard and assisting them in legal proceedings.

\section{References}

Abbott, P. (2008). The Cambridge introduction to narrative. Cambridge: Cambridge University Press.

Adichie, C. (2000). The danger of a single story. Retrieved from: https://pdfs.semanticscholar.org/10b7/0371dc6e1ae08ede73e813d29bb7ca78939b.pdf. [Accessed 25.2.2021].

Akeroyd, A. (1997). Sociocultural aspects of AIDS in Africa: Occupational and gender issues. In Bond G., Kreniske, J., Susser, I. and Vincent, J. (Eds.), AIDS in Africa and the Caribbean (pp. 11-30). Boulder: Westview Press.

Atkinson, P., Coffey, A., \& Delamont, S. (2003). Key themes in qualitative research: Continuities and changes. Lanham, MD: AltaMira Press.

Bartlett, K. T., Rhode, D., Grossman, J. L., \& Buchalter, S. (2014). Gender law and policy (2nd ed.). New York: Wolters Kluwer Law and Business.

Bass, A. (2015). Getting screwed: Sex workers and the law. Lebanon, NH: ForeEdge.

Basu, A., \& Dutta, M. J. (2011). 'We are mothers first': Localocentric articulation of sex worker identity as a key in HIV/AIDS communication. Women \& Health, 51(2), 106-123.Available at: https://doi.org/10.1080/03630242.2010.550992.

Bayles, C., \& Bujra, J. (2000). AIDS, sexuality and gender in Africa: Collective strategies and struggles in Tanzania and Zambia. London: Routledge.

Beckham, S. W. (2013). Like any other woman'? Pregnancy, motherhood, and HIV among sex workers in Southern Tanzania. PhD Thesis, Johns Hopkins University

Bell, L. (1987). Good girls/bad girls: Sex trade workers and feminists face to face. Toronto: Women's Press.

Bindel, J. (2017). The pimping of prostitution: Abolishing the sex work myth. London: Palgrave Macmillan.

Blatt, B. (1981). How to destroy lives by telling stories. Journal of Psychiatric Treatment and Evaluation, 3(2), 183-191.Available at: 0195$8127 / 81 / 020183-09$ S02.00/0.

Blumer, H. (1954). What is wrong with social theory? American Sociological Review, 19(1), 3-10.Available at: 10.2307/2088165.

Bogdan, R., \& Biklen, S. K. (1998). Qualitative research for education: An introduction to theory and method. Boston, MA: Allyn and Bacon.

Boylorn, M. R. (2008). Lived experience. In Given, M.L. (Ed.), The Sage encyclopedia of qualitative research methods (pp. 489-490). London: Sage.

Braun, V., \& Clarke, V. (2006). Using thematic analysis in psychology. Qualitative Research in Psychology, 3(2), 77-101.Available at: https://doi.org/10.1191/1478088706qp063oa.

Buberwa, D. (2016). Patriarchy ideology and workload inequality within household. Journal of Human-Social Science, 16(1), 1-9.

Christiansen, C., Utas, M., \& Vigh, H. E. (2006). Introduction: Navigating youth, generating adulthood. In Christiansen, C., Utas, M. and Vigh, H.E. (Eds.), Navigating youth, generating adulthood: Social becoming in an African context (pp. 9-28). Stockholm: Nordic Africa Institute.

Clandinin, J., \& Connelly, M. (2000). Narrative inquiry: Experience and story in qualitative research. San Francisco: Jossey-Bass.

Daly, M. (1985). Beyond god the father: Toward a philosophy of women's liberation. Boston, MA: Beacon Press.

Delacoste, F., \& Alexander, P. (1987). Sex work: Writings by women in the sex industry. San Francisco: Cleis Press.

Dickson-Swift, V., James, E., Kippen, S., \& Liamputtong, P. (2006). Blurring boundaries in qualitative health research on sensitive topics. Qualitative Health Research, 16(6), 853-871.Available at: 10.1177/1049732306287526.

Dickson, G., \& Green, K. (2001). The external researcher in participatory action research. Educational Action Research, 9(2), 242-260.Available at: https://doi.org/10.1080/09650790100200150. 
Ellett, J. (2011). Narrative and phenomenology as methodology for understanding persistence in art teachers: A reflective journey. Lowa Research Online, 1(2), 1-14.

Ellis, A., Blackden, M., Cutura, J., MacCulloch, F., \& Seebens, H. (2007). Gender and economic growth in Tanzania: Creating opportunities for women. Washington, DC: World Bank.

Farley, M. (2006). Prostitution, trafficking, and cultural amnesia: What we must not know in order to keep the business of sexual exploitation running smoothly. Tale Journal of Law and Feminism, 18(1), $101-136$.

Farley, M., Cotton, A., Lynne, J., Zumbeck, S., Spiwak, F., Reyes, M., \& Sezgin, U. (2003). Prostitution and trafficking in nine countries: An update on violence and posttraumatic stress disorder. Journal of Trauma Practice, 2(3-4), 37-74.Available at: https://doi.org/10.1300/J189v02n03_03.

Grenz, S. (2005). Intersections of sex and power in research on prostitution: A female researcher interviewing male heterosexual clients. Signs: Journal of Women in Culture and Society, 30(4), 2091-2113.Available at: https://doi.org/10.1086/428418.

Guignon, C. (1999). The Cambridge companion to Heidegger. Cambridge: Cambridge University Press.

Hagues, R., \& Parker, H. (2014). Girls' development in Tanzania: Empowering girls through creative exploration. Journal of Community Engagement and Scholarship, 7(2), 82-91.

Haram, L. (2003). Prostitutes' or modern women? Negotiating respectability in northern Tanzania. In Arnfred, S. (Ed), Re-thinking sexualities in Africa (pp. 211-229). Uppsala: Nordic Africa Institute.

Haram, L. (2005). Eyes have no curtains': The moral economy of secrecy in managing love affairs among adolescents in northern Tanzania in the time of AIDS. Africa Today, 51(4), 56-73.Available at: 10.1353/at.2005.0040.

Hardman, K. (1997). A social work group for prostituted women with children. Social Work with Groups, 20(1), 19-31.Available at: https://doi.org/10.1300/j009v20n01_03.

Hearn, J. (2012). A multi-faceted power analysis of men's violence to known women: From hegemonic masculinity to the hegemony of men. Sociological Review, 60(4), 589-610.Available at: https://doi.org/10.1111/j.1467-954X.2012.02125.x.

Heidegger, M. (2001). Being and time. Oxford: Wiley-Blackwell.

Henry, M. G. (2003). Where are you really from?': Representation, identity and power in the fieldwork experiences of a South Asian diasporic. Qualitative Research, 3(2), 229-242.Available at: https://doi.org/10.1177/14687941030032005.

Hofmann, T., Puzicha, J., \& Jordan, M. (1998). Learning from dyadic data. Cambridge, MA: MIT Press.

Hollos, M., \& Larsen, U. (2008). Motherhood in Sub-Saharan Africa: The social consequences of infertility in an urban population in Northern Tanzania. Culture, Health Eீ Sexuality, 1O(2), 159-173.Available at: https://doi.org/10.1080/13691050701656789.

ILO. (2013). Rural-urban migrants employed in domestic work: Issues and challenges. Dar es Salaam: ILO.

Kambarami, M. (2006). Femininity, sexuality and culture: Patriarchy and female subordination in Zimbabwe. Harare: Africa Regional Sexuality Resource Centre.

Karnieli-Miller, O., Strier, R., \& Pessach, L. (2009). Power relations in qualitative research. Qualitative Health Research, 19(2), 279289.Available at: $10.1177 / 1049732308329306$

Kempadoo, K. (1999). Slavery or work? Reconceptualizing third world prostitution. positions: East Asia Cultures Critique, 7(1), 225237.Available at: https://doi.org/10.1215/10679847-7-1-225.

Kiaga, A. K. (2007). Blaming the other woman: Rural housegirl and urban employers on identity, labour and migration in Tanzania. PhD Thesis, University of Minnesota.

Kibuga, F. (2000). The situation of child domestic workers in Tanzania: A rapid assessment. Dar es Salaam: UNICEF.

King, D. W. (1998). Deep talk: Reading African-American literary names. Charlottesville: Virginia University Press.

Kurtz, C. (2014). Working with stories in your community or organization: Participatory narrative inquiry (3rd ed.). Los Angeles: Kurtz-Fernhout Publishing.

Langdridge, D. (2007). Phenomenological psychology: Theory, research and method. Harlow: Pearson Education.

Leclerc-Madlala, S. (2003). Transactional sex and the pursuit of modernity. Social Dynamics: A Journal of African Studies, 29(2), 213233.Available at: 10.1080/02533950308628681.

MacKinnon, C. A. (1993). Prostitution and civil rights. Michigan Journal of Gender and Law, 1(1), 13-31.

Maher, L. (2000). Sexed work: Gender, race and resistance in a Brooklyn drug market. Oxford: Oxford University Press.

Matthews, R. (2008). Prostitution, politics and policy. New York: Routledge-Cavendish.

Maxey, I. (1999). Beyond boundaries? Activism, academia, reflexivity and research. Area, 31(3), 199-208.Available at: 10.1111/j.14754762.1999.tboo084.x.

May, T. (2000). Social research: Issues, methods and process. London: McGraw-Hill.

Mbonye, M., Nalukenge, W., Nakamanya, S., Nalusiba, B., King, R., Vandepitte, J., \& Seeley, J. (2012). Gender inequity in the lives of women involved in sex work in Kampala, Uganda. Journal of the International AIDS Society, 15(1), 1-9.Available at: 10.7448/IAS.15.3.17365.

McDowell, L., \& Pringle, R. (1992). Defining women: Social institutions and gender divisions. Oxford: Polity Press.

Mookodi, G. (2004). Male violence against women in Botswana: A discussion of gendered uncertainties in a rapidly changing environment. African Sociological Review, 8(1), 118-138.Available at: https://doi.org/10.4314/asr.v811.23240.

Msigwa, R., \& Mbongo, J. (2013). Determinants of internal migration in Tanzania. Journal of Economics and Sustainable Development, 4(9), 2835.

Ngugi, E. N., Roth, E., Mastin, T., Nderitu, M. G., \& Yasmin, S. (2012). Female sex workers in Africa: Epidemiology overview, data gaps, ways forward. Sahara J: Journal of Social Aspects of HIV/AIDS, 9(3), 148-153.Available at: 10.1080/17290376.2012.743825.

O'Leary, Z. (2004). The essential guide to doing research. London: Sage.

Ospina, S. (2004). Qualitative research. In Goethals, G., Sorenson, G. and Burns, J. (Eds.), Encyclopaedia of leadership (pp. 1279-1284). Thousand Oaks: Sage.

Overall, C. (1992). What's wrong with prostitution? Evaluating sex work. Signs: Journal of Women in Culture and Society, 17(4), 705724.Available at: https://doi.org/10.1086/494761.

Preston-Whyte, E., Varga, C., Oosthuizen, H., Roberts, R., \& Blose, F. (2000). Survival sex and HIV/AIDS in an African city. In Parker, R., Barbosa, M.R. and Aggleton, P. (Eds.), Framing the sexual subject: The politics of gender, sexuality, and power (pp. 165-190). Berkeley: University of California Press.

Quinn, K. A., \& Rosenthal, H. E. S. (2012). Categorizing others and the self: How social memory structures guide social perception and behaviour. Learning and Motivation, 43(4), 247-258.Available at: https://doi.org/10.1016/j.lmot.2012.05.008.

Riessman, C. K. (2008). Narrative methods for the human sciences. Los Angeles: Sage.

Rubin, G. (1984). Thinking sex: Notes for a radical theory of the politics of sexuality. In Vance, S.V. (Ed.), Pleasure and danger: Exploring female sexuality (pp. 267-319). Boston: Routledge and Kegan Paul.

Safranski, R. (1998). Martin Heidegger: Between good and evil. Cambridge, MA: Harvard University Press.

Savin-Baden, M., \& van Niekerk, L. (2007). Narrative inquiry: Theory and practice. Journal of Geography in Higher Education, 31(3), 459472.Available at: https://doi.org/10.1080/03098260601071324.

Scheibe, A., Drame, F. M., \& Shannon, K. (2012). HIV prevention among female sex workers in Africa. SAHARA J: Journal of Social Aspects of HIV/AIDS, 9(3), 167-172.Available at: 10.1080/17290376.2012.743809.

Scorgie, F., Chersich, M. F., Ntaganira, I., Gerbase, A., Lule, F., \& Lo, Y. R. (2012). Socio-demographic characteristics and behavioural risk factors of female sex workers in Sub-Saharan Africa: A systematic review. AIDS and Behaviour, 16(4), 920-933.Available at: $10.1007 / \mathrm{s} 10461-011-9985-\mathrm{z}$.

Scorgie, F., Nakato, D., Harper, E., Richter, M., Maseko, S., Nare, P., \& Chersich, M. (2013). We are despised in the hospitals: Sex workers' experiences of accessing health care in four African countries. Culture, Health and Sexuality, 15(4), 450-465.Available at: $10.1080 / 13691058.2012 .763187$.

Setel, P. (1999). A plague ofparadoxes: AIDS, culture, and demography in Northern Tanzania. Chicago: University of Chicago Press.

Shaw, R. (2010). Embedding reflexivity within experiential qualitative psychology. Qualitative Research in Psychology, 7(3), 233-243.Available at: $10.1080 / 14780880802699092$. 
Silberschmidt, M. (2001). Disempowerment of men in rural and urban East Africa: Implications for male identity and sexual behaviour. World Development, 29(4), 657-671.Available at: https://doi.org/10.1016/S0305-750X(00)00122-4.

Smith, F., \& Marshall, L. (2007). Barriers to effective drug addiction treatment for women involved in street level prostitution: A qualitative investigation. Criminal Behaviour and Mental Health, 17(3), 163-170.Available at: https://doi.org/10.1002/cbm.654.

Stark, L. (2017). Cultural politics of love and provision among poor youth in urban Tanzania. Ethnos, 82(3), 569-591.Available at: https://doi.org/10.1080/00141844.2015.1080749.

Strauss, A., \& Corbin, J. (1998). Basics of qualitative research. Newbury Park, CA: Sage.

Swantz, M.-L. (2007). The role of local government in strengthening women's economy: Women's livelihood and productive groups in Iramba district. Unpublished Document.

Swidler, A., \& Watkins, C. S. (2007). Ties of dependence: AIDS and transactional sex in rural Malawi. Studies in Family Planning, 38(3), 147162.Available at: 10.1111/j.1728-4465.2007.00127.x.

Tang, N. (2002). Interviewer and interviewee relationships between women. Sociology, 36(3), 703-721.Available at: https://doi.org/10.1177/0038038502036003011.

Thomas, D. (2006). A general inductive approach for analysing qualitative evaluation data. American Journal of Evaluation, 27(2), 237246.Available at: https://doi.org/10.1177/1098214005283748.

UNICEF. (2006). Child domestic workers and access to education in Makete, Tanzania. Dar es Salaam: UNICEF.

van Manen, M. (1990). Researching lived experience: Human science for an action sensitive pedagogy. Albany: State University of New York Press.

Varkevisser, C. (1973). Socialization in a changing society: Sukuma childhood in rural and urban Mwanza, Tanzania. PhD Thesis, University of Amsterdam.

Wamoyi, J., Fenwick, A., Urassa, M., Zaba, B., \& Stones, W. (2011). Women's bodies are shops: Beliefs about transactional sex and implications for understanding gender power and HIV prevention in Tanzania. Archives of Sexual Behaviour, 4O(1), 5-15.Available at: $10.1007 / \mathrm{s} 10508-010-9646-8$.

Watt, D. (2007). On becoming a qualitative researcher: The value of reflexivity. Qualitative Report, 12(1), 82-101.

Zalwango, F., Eriksson, L., Seeley, J., Nakamanya, S., Vandepitte, J., \& Grosskurth, H. (2010). Parenting and money making: Sex work and womens choices in urban Uganda. Wagadu, 8, 71-92. 